\title{
Kosovo - når virkeligheden er svær at styre
}

Thomas Hjorts $\emptyset$

\section{Det begyndte som en proces, der så fuldstændig forudsigelig ud. Alt tegnede til et selvstændigt Kosovo. Siden blev processen trukket i langdrag og førte usikkerhed og ustabilitet med sig}

"Kosovo skal være et multi-etnisk samfund, som skal styre sig selv demokratisk".

Sådan lyder indledningen til den finske FN-mægler Martti Ahtisaaris plan for et nyt Kosovo. Senere hedder det, at Kosovo skal have ret til at indgå internationale aftaler for eksempel i internationale organisationer. Og Kosovo skal have sine egne særlige nationale symboler, herunder et flag, segl og nationalsang, der afspejler dets multietniske karakter, som det hedder i planen.

Det var det nærmeste, som den tidligere finske præsident kom på at kalde Kosovo for et selvstændigt land, da han offentliggjorde sin plan i februar 2007. For ordet selvstændighed er slet ikke nævnt i selve aftalen, og ordet land eller stat undgås med samme behændighed. Når Ahtisaari ikke nævner det, så er det for at imødekomme serberne, som ikke vil give slip på Kosovo.

Men reelt får Kosovo med planen mulighed for at optræde som et land og for eksempel samarbejde med Den Internationale Valutafond, hvad der anses for vigtigt for at fremme en $\varnothing$ konomisk udvikling. Og ifølge planen er det ikke noget til hinder for, at lande kan anerkende Kosovo.

Et andet gennemgående træk i den finske mæglers plan er garantier til mindretallene - især det serbiske mindretal, som tæller under 10 procent.

For eksempel bliver de officielle sprog albansk, som flertallet benytter, og så serbisk. Der er også garantier for, at man ikke må diskriminere, når man ansætter medarbejdere - især i det offentlige. Også den serbisk-ortodokse kirke får en særstil- 
ling, ligesom de ortodokse kirker og klostre skal beskyttes.

\section{Luftige formuleringer}

Men Ahtisaaris plan indeholder også mere vage formuleringer, som at Kosovos myndigheder i deres politik og udførelsen af den skal lade sig lede af et behov for at fremme en ånd af fred, tolerance og interkulturel og religiøs dialog - mellem alle samfund og deres medlemmer. Måske noget luftigt og svært at kontrollere.

Ellers er der mange kontrolmekanismer lagt ind. Der skal blandt andet udpeges en international civil repræsentant, som skal overvåge og kontrollere udviklingen. Det kommer til at foregå efter forbillede fra et andet Balkan-land, nemlig Bosnien, hvor en international repræsentant har stor magt.

I Kosovo skal den internationale repræsentant ligesom i Bosnien kunne nedlægge veto mod nye love. Og områder som politi og retsvæsen bliver særlig nøje kontrolleret af Den Europæiske Union. Der er ikke sat en frist på, hvor længe der skal være international kontrol i Kosovo, kun at et internationalt råd skal vurdere indsatsen - senest to år efter, at Ahtisaaris plan er trådt i kraft.

Og så skal der i Kosovo fortsat være en fredsstyrke som den i dag, der tæller blandt andre danske soldater. Styrken skal forblive under NATOs ledelse, og NATO skal også uddanne og kontrollere den lette hær, som Kosovo får lov til at have. Og som skal opbygges på resterne af Kosovos nuværende beredskabslignende korps, der formelt skal nedlægges i løbet af et år.

\section{Uro satte skred i planer}

Den tidligere danske FN-chef i Kosovo, Søren Jessen-Petersen, betegner Ahtisaaris plan som god og vigtig, fordi den peger i retning af selvstændighed, som er det eneste, der kan stabilisere Kosovo og hele regionen.

Søren Jessen-Petersen havde helt særlige beføjelser, da han tog over som FN-chef i Kosovo i sommeren 2004. Det skete kort efter de værste uroligheder, siden NATO rykkede ind i Kosovo i 1999. Under yderligtgående albaneres angreb på serbere blev 19 dræbt i foråret 2004.

Uroen førte paradoksalt nok til, at Søren Jessen-Petersen som den første FN-chef i Kosovo havde mulighed for at tale om selvstændighed for Kosovo.

Indtil da mente det internationale samfund, at man ikke kunne give det kosovo-albanske flertal uafhængighed fra Serbien, fordi demokratiet ikke havde udviklet sig ordentligt, og fordi man ikke følte sig sikker på, at det serbiske mindretal ville kunne klare sig.

Men volden i marts 2004 førte altså til, at det internationale samfund besluttede sig for at give Koso- 
vo selvstændighed. Det var den eneste måde, hvorpå man kunne lægge en dæmper på kosovo-albanerne, mente man.

Søren Jessen-Petersen satte skred i bevægelsen mod et selvstændigt Kosovo allerede fra august 2004, da han tiltrådte. Han har senere erkendt, at han var heldigere stillet end sine forgængere i Kosovo, fordi han havde lov til at tale om områdets status.

\section{Planmæssigt sammenbrud}

I begyndelsen af 2006 begyndte forhandlinger mellem Serbien og kosovo-albanske repræsentanter om en ny status for Kosovo. Det skete under ledelse af Martti Ahtisaari og hans medarbejdere. Det var ventet, at Kosovo kunne få en form for selvstændighed allerede i slutningen af året. Forholdsvis planmæssigt førte forhandlingerne ikke til noget. Det var klart, at parterne stod for langt fra hinanden.

Men så i efteråret 2006 tog Serbien hul på en forhalingstaktik, der skulle vise sig at blive meget vellykket. Først holdt Serbien den 28. oktober en folkeafstemning om en ny grundlov, der blandt andet slog fast, at Kosovo er en uadskillelig del af Serbien. Da den var vedtaget, blev der udskrevet nyvalg. I den periode respekterede Martti Ahtisaari og hans hold et serbisk ønske om en pause i forhandlingerne og for at offentliggøre et forslag, der skulle træ- de i stedet for en forhandlet løsning.

Efter det serbiske parlamentsvalg den 21. januar 2007 offentliggjorde Ahtisaari sin plan, men da havde en vis nervøsitet sat ind - blandt andet $\mathrm{i}$ flere EU-lande, der ellers sammen med USA var tilhængere af at give Kosovo en form for selvstændighed. Et land som Italien talte også om at give Serbien noget til gengæld for udsigten til at miste Kosovo.

Kravet fra Italien og andre EU-lande var, at unionen skulle gå med til en stabiliserings- og associeringsaftale uden den hidtidige betingelse om, at Serbien først skulle udlevere den krigsforbryderanklagede general Ratko Mladic.

\section{Det forbudte ord}

Mens nervøsiteten voksede, tog den finske FN-mægler Martti Ahtisaari det dristige skridt i marts 2007 at bruge ordet selvstændighed, da han fremlagde sin plan for Kosovos fremtid for FN's Sikkerhedsråd. Det skete i en følgeskrivelse, hvor han anbefaler et selvstændigt Kosovo.

Dermed satte han i virkeligheden kun ord på den situation, som hans plan fører til. Ifølge en kilde tæt på forhandlingerne tog han konsekvensen af, at spillet syntes ude for Serbien.

I et forsøg på at redde Kosovo satsede Serbien på at vinde tilhængere i FN's Sikkerhedsråd eller satte sin lid til, at Rusland ville nedlægge veto i Sikkerhedsrådet. Men Rus- 
land syntes på det tidspunkt at være ved at få kolde fødder. Rusland har sagt, at det ikke vil støtte en plan, som en af parterne er imod. Men det har aldrig sagt, at det vil nedlægge veto.

For at lægge pres på Rusland kom den tidligere amerikanske Balkanmægler Richard Holbrooke med trusler. Hvis Kosovo må vente med at blive selvstændigt, kan det komme til vold - ja måske en ny krig i løbet af nogle få dage i Kosovo, sagde han i temmelig voldsomme vendinger.

Rusland vil komme til at bære ansvaret, og det vil påvirke Ruslands forhold til Vesten, advarede Richard Holbrooke, der var mægler under krigen i Bosnien. Han udtalte sig som privatperson, men han menes stadig at være tæt på det amerikanske udenrigsministerium.

Det skete, mens FN-mægler Ahtisaari rejste verden rundt for at samle støtte til sin plan og forklare den over for medlemmerne af FN's Sikkerhedsråd. Ahtisaari og hans medarbejdere har udtrykkeligt sagt, at et selvstændigt Kosovo er et særtilfælde. Det vil ikke føre til, at andre lignende områder lovligt kan rive sig løs, mener de. Og det er også holdningen i vestlige lande, der er tilhængere af et selvstændigt Kosovo.

Men da var frygten for, at Kosovo kunne smitte, begyndt at sprede sig langt ind i Den Europæiske Union. Lande som Spanien og Slovakiet blev bange for, at et selvstændigt Ko- sovo vil få mindretal til at rive sig løs. I Spaniens tilfælde Baskerlandet eller Katalonien. Og Slovakiet frygtede for det ungarske mindretal, der især bor i den sydlige del af landet.

Også i Ruslands nabolande ligger flere områder, som kunne lade sig inspirere. Det gælder for eksempel udbryderområderne Abkhasien og Sydossetien i Georgien og Transdnjestr i Moldavien.

Alle de tre områder er knyttet til Rusland, og man kunne måske tro, at et selvstændigt Kosovo kunne bruges til at argumentere for, at de tre område skulle rive sig løs. Det har Rusland også delvist gjort, men analytikere mener, at Rusland kan få mere ud af at fastholde den usikre situation, som den er i dag.

Et argument mod, at de tre områder skulle rive sig løs eller slutte sig sammen er Tjetjenien, som så efter samme logik skulle have lov til at blive selvstændigt.

Der er i øvrigt mange forskelle mellem de tre områder og Kosovo, som gør det svært at sammenligne. For eksempel boede der tidligere mange georgiere i Abkhasien, men stort set alle blev fordrevet, da området brød ud af Georgien i begyndelsen af 1990'erne.

\section{Bosnien som næste dominobrik}

Princippet om at ændre et lands grænser, som der reelt er tale om, når man vil skille Kosovo fra Serbien, har også konsekvenser langt ud 
over Europa. Og flere af Sikkerhedsrådets medlemmer menes at lægge meget vægt på, hvilke konsekvenser det kan få for løsrivelsestendenser i deres eget land. Det gælder for eksempel Kina med Tibet - og Indonesien med Aceh.

Men måske vil de værste konsekvenser af et selvstændigt Kosovo kunne findes i nabolaget. Her har man længe har talt om, at et selvstændigt Kosovo kan inspirere andre regioner til at bryde ud. For eksempel albanerne i nabolandet Makedonien.

Eller Bosnien-Hercegovina. Her begyndte Kosovo at rumle allerede $\mathrm{i}$ foråret 2006, efter at de politiske partier i Bosnien ikke kunne blive enige om en ny grundlov. Den skulle have skabt en mere effektiv og moderne stat, men også en stat med et mere centralt styre. Og det ville så være gået ud over Den Serbiske Republiks selvstyre, som var en del af Dayton-fredsaftalen fra 1995. Dayton-aftalen delte Bosnien op i to delstater: Den Serbiske Republik og så en føderation af kroater og bosniakker, der er de bosniske muslimer.

Ændringerne i grundloven blev støttet af Den Europæiske Union og USA. Men det mislykkede fors $ø g$ satte i stedet gang i en nationalistisk bølge hos alle de tre store befolkningsgrupper i Bosnien: serbere, kroater og bosniakker.

Den nationalistiske bølge fik mere fart på i maj 2006, da naboen Mon- tenegros vælgere besluttede sig for at forlade unionen med Serbien. Straks derefter kom regeringschef Milorad Dodik med et forslag om en folkeafstemning om at erklære Den Serbiske Republik selvstændig fra Bosnien - et krav han har gentaget mange gange. Når han henvender sig til vestlige medier, hedder det sig, at en folkeafstemning kun er et svar til bosniakkiske politikere, der kræver, at Den Serbiske Republik bliver nedlagt.

Retorikken tog til før et valg $\mathrm{i}$ Bosnien i oktober 2006. Og selv om retorikken kunne ses som bragesnak, så blev den også udlagt som et tegn på de fundamentale problemer i Bosnien: At det er meget svært at skabe en levedygtig og velfungerende stat. Et problem som er blevet mere og mere åbenlyst i de senere år.

\section{Teheran i Sarajevo}

Milorad Dodik har fat i den lange ende med sin retorik i den forstand, at alle meningsmålinger siger, at 90 procent af indbyggerne i Den Serbiske Republik ikke anser Bosnien for deres land. Regeringschef Dodik har senere optrappet sit sprog blandt andet ved at fortælle om sin søn, der kalder Sarajevo for Teheran - en henvisning til det muslimsk dominerede Sarajevo.

Milorad Dodik talte også direkte om Kosovo, og sagde, at hvis det blev uafhængigt, ville det føre til uro 
i hans republik. Noget, som analytikere nok mener, er noget overdrevet. Og Dodik ved, at Dayton-aftalen udelukker en folkeafstemning om at rive dele af Bosnien løs. Den serbiske leders sammenligning med Montenegro holder i øvrigt ikke helt, fordi Montenegro brugte sin folkeafstemning til at søge selvstændighed fra Serbien, mens serberne i Bosnien i første række vil bruge en folkeafstemning til at blive selvstændige fra Bosnien, men så uden tvivl søge sammen med Serbien - altså det modsatte af Montenegro.

Umiddelbart før valget i Bosnien i oktober 2006 sagde Dodik, at tidligere tiders drøm om at slutte hans republik til moderlandet Serbien, stadig er realistisk. Det skete i forbindelse med, at serberne i Bosnien indgik en aftale med Serbien om tættere forbindelser, og det er nok ikke noget tilfælde, at den blev skrevet under nogle få dage før valget.

Aftalen handler om at samarbejde på økonomiske, sociale og kulturelle områder. Den er magen til en, der blev indgået med Jugoslavien fem år før. Men da Jugoslaviens sidste medlemmer Serbien og Montenegro besluttede sig for at gå hver til sit, blev Serbien og Den Serbiske Republik enige om et samarbejde.

Bosniakkiske politikere protesterede og sagde, at Serbien burde indgå aftaler med hele Bosnien i stedet. Men den internationale repræsentant i Bosnien sagde god for arrangementet, som der er hjemmel for i
Dayton-aftalen. Det var måske især tidspunktet kort før valget, som de bosniakkiske politikere fandt betænkeligt.

Retorikken fra Milorad Dodik og andre serbiske politikere i Bosnien kan nemt være styret fra moderlandet Serbien. Det mente blandt andre den politiske analytiker Tanja Topic fra serbernes hovedby i Banja Luka. Hun tænkte især på Serbiens regeringschef Vojislav Kostunica, som hun anklagede for at have brugt politikerne i Den Serbiske Republik til at fremme Serbiens sag i Kosovo ved at advare Vesten om, hvad et selvstændigt Kosovo kan føre til.

Milorad Dodik vandt stort valget i Den Serbiske Republik i oktober 2006, og det skyldes efter alt at dømme hans nationalistiske tone. Også blandt bosniakkerne kom nationalister til magten.

Efter valget fortsatte Milorad Dodik med sin retorik. Omvendt blev angrebene på Den Serbiske Republik forstærket, efter at Den Internationale Domstol i Haag den 26. februar 2007 slog fast, at der var begået folkedrab på bosniakker i Srebrenica. Men Serbien var ikke skyldig, afgjorde domstolen, der dømmer mellem stater og altså ikke må forveksles med krigsforbrydertribunalet i Haag.

Den Internationale Domstol mere end antydede, at ansvaret for folkedrabet altså skulle lægges på de daværende myndigheder i Den Serbi- 
ske Republik. Noget som krigsforbryderdomstolen i Haag også er nået frem til.

Den internationale domstols afgørelse førte til krav fra især den ledende bosniakkiske politiker Haris Silajdzic om at nedlægge Den Serbiske Republik, fordi den er skabt på folkedrab, som han siger. Haris Silajdzic, der var udenrigsminister og regeringschef under krigen i Bosnien fra 1992-95, kan med god ret ses som en bosniakkisk nationalist, selv om han vil nedlægge både Den Serbiske Republik og Føderationen af kroater og bosniakker.

Hans ønske om at skabe en enhedsstat kan se uskyldigt ud, men hans benhårde angreb på Den serbiske Republik og dermed Dayton-aftalen falder i en nationalistisk dyst.

\section{Badinter-kommissionen}

Når man skal se på, hvilke områder i det tidligere Jugoslavien, der har ret til at blive selvstændige, skal man tilbage til Jugoslaviens opløsning i 1991-92. Dengang blev der nedsat en kommission af internationale folkeretseksperter under ledelse af franskmanden Robert Badinter.

Gruppen nåede blandt andet frem til, at de seks jugoslaviske republikker havde ret til at blive selvstændige. De seks er Serbien, Kroatien, Slovenien, Bosnien-Hercegovina, Montenegro og Makedonien. Altså hverken Den Serbiske Republik i Bosnien, som er et resultat af krigen, eller Kosovo, der sammen med Vojvodina havde en særlig status som selvstyrende område inden for Serbien, før krigene brød ud.

Andre folkeretseksperter har siden argumenteret mod Badinterkommissionens konklusion med, at Serbien mistede retten til Kosovo ved sin brutale fremfærd i området. Et andet modargument har været, at Kosovo de facto var en republik i Jugoslavien, blandt andet fordi området sendte en repræsentant til det jugoslaviske præsidentråd på linje med de seks republikker. Vojvodina sendte også en repræsentant, og derfor havde de to også ret til at træde ud af Jugoslavien.

Men hvis man har lov til at skille Kosovo ud i strid med den mest almindeligt accepterede udlægning, hvorfor kan man så ikke dele Kosovo i en serbisk og en albansk del? Og meget tydede på, at det var, hvad Serbien prøvede i slutspillet, og måske var det også et mål for hele den serbiske forhalingstaktik. Som led i taktikken fik Serbien sammen med Rusland sendt en delegation fra FN's Sikkerhedsråd til Kosovo i april 2007 for at samle flere oplysninger ind.

\section{Et delt Kosovo}

Serbiens satsede med forhalingstaktikken tilsyneladende på at redde den nordlige del af Kosovo - den er i forvejen noget nær rent serbisk. Den ligger ved og især nord for 
byen Mitrovica, hvor der i de seneste år har været voldsomme sammenstød mellem serbere og albanere. Området udgør 15 procent af Kosovos areal og her bor op mod 50.000 serbere. Serbiske ledere i området havde truet med at rive området løs, hvis Kosovo blev selvstændigt. Nyhedsbureauet Reuters citerede i foråret 2007 serbiske kilder for, at Serbiens regering i det stille var i færd med at opkøbe albanske huse i det nordlige Kosovo.

Der kom også andre tegn fra Serbien på, at man arbejdede på at få delt Kosovo op. Serbiens tidligere udenrigsminister Goran Svilanovic gik ind for det. Han er kendt som moderat, og han sagde, at Serbien skulle bede om en særlig status for det nordlige Kosovo, hvorefter man om et par år skulle se på situationen igen. Her kan det så komme på tale med en korrektion, som han kaldte det, af grænsen mellem Serbien og Kosovo.

Også lederen af den serbiske regerings Kosovo-kontor spurgte, hvorfor det ikke skulle være muligt at ændre grænserne i et selvstændigt Kosovo.

Tidligere - for eksempel i 1990' erne - dukkede der ind i mellem serbiske forslag om at dele Kosovo op, men stemningen i Serbien vendte i løbet af foråret 2007 til et mere massivt ønske. Den amerikanske analytiker James Lyon, der bor i Serbiens hovedstad Beograd, sagde, at han efter samtaler med serbere af alle politiske overbevisninger nåede til den konklusion, at en opdeling af Kosovo var blevet en populær ide fra det yderste højre til det yderste venstre.

Et argument er ifølge Balkan-kenderen og journalisten Tihomir Loza, at fordi kosovo-serberne er blevet forfulgt siden 1999, så har de lige så meget fortjent at blive selvstændige, som kosovoalbanerne fortjente det med deres lidelser før den periode.

Måske vil kosovoalbanske politikere med tiden komme til den erkendelse, at man lige så godt kan give slip på det nordlige Kosovo, skrev Tihomir Loza i Transitions Onlineog sammenlignede med, at serbiske politikere nok også på et tidspunkt vil komme til den konklusion, at det trods alt var bedre at slippe af med den byrde, som Kosovo også har været for Serbien.

\section{Fælles interesser}

Stort set de eneste serbere, der går imod at dele Kosovo op, synes at være den ortodokse kirke. Der findes nemlig ingen store minder som kirker og klostre i den nordlige del af Kosovo, men derimod mange i den sydlige.

I Kosovo går det store flertal af albanere klart imod at dele Kosovo op, men der er en lille gruppe nationalistiske albanere, der i virkeligheden deler interesser med serbiske nationalister, skrev Tihomir Loza. Nationalisternes interesser kan falde 
sammen, hvis Kosovo bliver utålmodig og erklærer sig selvstændig uden at vente på en afgørelse i FN, eller hvis en afgørelse går kosovoalbanerne imod.

Derefter kunne det komme på tale, at Kosovo erklærede sig selvstændigt. Ja, det var en mulighed, som USA og vestlige lande havde ladet sive vil blive løsningen, hvis ikke Rusland og andre gik med til Ahtisaari-planen. Og det kunne se ud som om, de havde fat i den lange ende, for processen var kommet så vidt, at det ikke vil være muligt at nægte kosovoalbanerne et selvstændigt land. Trods alt udgør de også omkring 90 procent af indbyggerne. Dertil kom frygten for vold fra ekstremistiske albanere.

En erklæring om selvstændighed fra Kosovos parlament ville efter al sandsynlighed blive mødt med en tilsvarende fra serbere i det nordlige Kosovo, og det ville blive fulgt op med en masseflugt fra de serbiske enklaver i det øvrige Kosovo, fordi serberne i enklaverne er mere udsatte. Den flugt, som ekstremistiske albanere måske gerne vil opnå for at få et stort område, der er renset for serbere.

Derfor er det vigtigt at undgå en situation, hvor serberne i nord river sig løs, mener Søren Jessen-Petersen, som også mener, at det internationale samfund skulle gøre Serbien klart, at det vil få konsekvenser. Hverken EU eller USA synes nu at have haft travlt med at advare Serbi- ens ledelse. Hele situationen i Serbien blev belastet af, at en ny regering stadig ikke var blevet udpeget flere måneder efter valget i januar. Tilsyneladende ville ingen serbiske politikere træde til og risikere at tage det formelle ansvar for at miste Kosovo.

\section{Ny centrifugalkraft}

Imens fortsatte Kosovo med at inspirere områder til at rive sig løs. Selv den nordlige serbiske provins Vojvodina med et betydeligt ungarsk mindretal så sig indblandet i striden. Den tyske ambassadør i Serbien foreslog uforsigtigt i april 2007, at Ungarn kunne sætte spørgsmålstegn ved Serbiens ret til Vojvodina, hvis ikke Serbiens anerkendte Kosovos ret til at blive selvstændigt. En noget besynderlig sammenhæng, men Ungarn følte sig nødsaget til at skride ind og gøre opmærksom på, at det ikke har noget krav på Vojvodina.

Parallellerne med Kosovo blev også drevet ud i det absurde. For eksempel krævede en borgmester fra det græske mindretal i det sydlige Albanien i maj 2007, at en stribe land ind mod Grækenland fik samme status som Kosovo - altså selvstændighed.

Samtidig med denne centrifugalkraft af områder, der også kræver en Kosovo-løsning, skete det modsatte. For eksempel sagde Makedoniens udenrigsminister, at landet er rede 


\section{THOMAS HJORTS $\varnothing$}

til at overveje at følge USA og andre vestlige lande og anerkende Kosovo, hvis der ikke bliver fundet en løsning. Makedoniens slaviske flertal stiller sig ellers mistænksomt over for et selvstændigt Kosovo, og hvilke følger det kan få for det albanske mindretal i Makedonien. I 2001 stod væbnede albanere bag et flere måneder langt oprør i Makedonien.

Men regeringen i Makedonien er så interesseret $\mathrm{i}$ at følge især USA men også $\mathrm{EU}$, at den er villig til at gå langt i Kosovo-spørgsmålet. Makedonien vil gerne optages i både NATO og EU. Og det er den pædagogiske effekt af ønsket om at blive medlem af de to organisationer, der kan lægge en dæmper på nye løsrivelsestendenser på Balkan. I sidste ende er det måske også kun Den Europæiske Union, der med samarbejdsaftale og til sidst medlemskab kan lokke Serbien til at give afkald på Kosovo.

Men unionen stod over for store udfordringer med blandt andet at tage stilling til at opgive sit krav om, at Serbien skal udlevere general Mladic, og samtidig skulle EU håndtere de stærke nationalistiske tendenser i Serbien.

Thomas Hjortsø er journalist ved DR's Orientering, P1, med Østeuropa og Balkan som speciale. 